\title{
Vegetation-free Area Surrounding Newly Planted 'Niagara' Grapevines Affects Vine Growth
}

\author{
Thomas J. Zabadal ${ }^{1}$ and \\ Thomas W. Dittmer ${ }^{2}$
}

AdDITIONAL INDEX WORDS. weed control, vineyard floor management, Vitis

SUMmARY. Varying amounts of vegetation-free area (VFA) were established around newly planted 'Niagara' ( Vitis labrusca L. x Vitis vinifera L.) grapevines to determine their influence on vine growth during the first growing season. VFAs were either circular with radii from 0 to $5 \mathrm{ft}$ $(0$ to $152 \mathrm{~cm})$ in one experiment or in bands from 0 to $8 \mathrm{ft}(0$ to $244 \mathrm{~cm})$ in width in a second experiment. VFAs were maintained with biweekly manual weeding for the entire growing season. Leaf, shoot and root dry weights as well as the number of primary shoots and the length of the longest root were measured at the end of their first growing season. The thresholds for maximum vine dry weight biomass accumulation occurred with a circular VFA of $4 \mathrm{ft}(122 \mathrm{~cm})$. When banded VFAs were used, total vine dry weight biomass continued to increase up to the widest treatment of $8 \mathrm{ft}(244 \mathrm{~cm})$. Therefore, no threshold was attained. These are greater VFAs than typically established around vines in commercial plantings. Therefore, growers who desire to maximize vine growth of newly planted vines, should consider larger VFAs around vines than has been traditional unless such a practice is likely to cause surface soil erosion.

Whe size of a vine is directly

Department of Horticulture, Michigan State Univer sity, East Lansing, MI 48824.

We thank James Ertman, Jerry Grajauskis, Fred Froehlich, and Gaylord Brunke for technical assistance, Diane Dings for preparation of the manuscript, and the Michigan Agricultural Experiment Station for financial support. The cost of publishing this paper was defrayed in part by the payment of page charges. Under postal regulations, this paper therefore must be hereby marked advertisement solely to indicate this fact.

${ }^{1}$ Associate professor.

${ }^{2}$ Former research technician. 
capacity (Winkler etal., 1974).

Therefore, it is desirable to increase the size of newly planted vines as rapidly as possible. The growth of weeds around new fruit plantings of apple (Malus $\times$ domestica Borkh.) (Hipps et al., 1990; Merwin and Ray, 1997), blueberry (Vaccinium ashei Reade) (NeSmith and Krewer, 1995), peach [Prunus persica (L.) Batsch] (Welker and Glenn, 1985, 1989, 1991) and grape (Vitis labrusca $\times$ Vitis vinifera) (Zabadal and Dittmer, 2000) have been shown to depress their growth. The concept of a damage threshold to relate the vegetation-free area (VFA) around a plant to its productivity has been defined as, "the weed population at which a crop response can first be measured." (Coble et al., 1981). Spatial (Welker and Glenn, 1985; 1989, 1991; Merwin and Ray, 1997; NeSmith and Krewer, 1995) as well as temporal (Merwin and Ray, 1997) damage thresholds that relate the influence of VFAs to several crops have been evaluated. However, no VFA relationships have been established for vine growth in eastern U.S. viticulture, where recommendations for VFA band width around vines have ranged from 2 to $4 \mathrm{ft}(61$ to $122 \mathrm{~cm}$ ) (Wolf and Poling, 1995; Shaulis and Steel, 1969; Kennedy et al., 1979; Cahoon et al., 1991; Zabadal, 1997). Extensive new acreage of the 'Niagara' juice grape variety is being established in several eastern U.S. viticultural regions. The rapid development of vine size and productivity in these new vineyards is of great economic importance to growers. Therefore, two experiments were conducted to determine the VFA thresholds for maximizing biomass accumulation of newly planted 'Niagara' vines.

\section{Materials and methods}

'Niagara' grapevines were planted in mid-May on a Spinks sandy loam soil at the Southwest Michigan Research and Extension Center near Benton Harbor, Mich. The site had been sewn to a rye (Secale cereale L.) cover the previous September, sprayed with glyphosate herbicide 2 weeks before planting and then disced. The first experiment was planted in 1995 with vines on a $10-\mathrm{ft}(3-\mathrm{m})$ square grid to evaluate vegetation-free areas in circular patterns around vines as is sometimes practiced by small growers. Treatments were VFAs with radii of $0,1,2$, 3,4 , and $5 \mathrm{ft}(0,30,61,91,122$, and $152 \mathrm{~cm}$ ). Treatments were arranged in a randomized complete block design with five blocks. There were two replicates of one vine each per treatment per block. Vines in a second experiment were planted in 1996 at a spacing of $7 \mathrm{ft}(2.1 \mathrm{~m})$ between vines and $10 \mathrm{ft}$ $(3.0 \mathrm{~m})$ between rows. Treatments included VFA band widths of $0,3,4$, $5,6,7$, and $8 \mathrm{ft}(0,91,122,152,183$, 213 , and $244 \mathrm{~cm}$ ). Each treatment was replicated five times in a completely random design. Experimental units had six vines and data were collected from the middle four vines. For both experiments, vines were fertilized with the equivalent of $30 \mathrm{lb} /$ acre $\left(33.6 \mathrm{~kg} \cdot \mathrm{ha}^{-}\right.$ ${ }^{1}$ ) of actual $\mathrm{N}$ applied immediately after planting by ringing each vine in a $2 \mathrm{ft}(61 \mathrm{~cm})$ diameter circle with ammonium nitrate, sprayed at 3 -week intervals to control disease and insect pests and left trailing along the ground.
VFAs were maintained throughout the growing season with manual weeding at biweekly intervals. Areas outside the VFAs were dominated by the weed species common ragweed (Ambrosia artemisiifolia L.), lambsquarters (Chenopodium album L.) and crabgrass (Digitaria sanguinalis L.) and were mowed at 4-week intervals throughout the growing season. Vines were not irrigated. Data were analyzed using SAS statistical software for analysis of variance followed by a comparison of treatment means with Fisher's test for least significance. Vines were completely harvested in mid-September and evaluated for leaf, shoot and root dry weight as well as the number of primary shoots. Roots were easily excavated intact from the light sandy soil, washed and then measured for the longest root on each vine. All tissues were dried at $70{ }^{\circ} \mathrm{C}$ for $120 \mathrm{~h}$ before recording tissue dry weights.

\section{Results and discussion}

Another study (Bordelon and Hubertz, 1999) indicated that planting vines into rye residues, as done in this study, can suppress vine growth. Nevertheless, vine growth under the conditions of these experiments was very responsive to the VFA around vines. When the VFA was established in a circular shape, a VFA with a $\mathrm{lft}$ $(30 \mathrm{~cm})$ radius produced no more vine biomass accumulation than the absence of a VFA (Table 1). However, a VFA with a $2 \mathrm{ft}(61 \mathrm{~cm})$ radius significantly increased vine biomass over the control treatment (Table 1 ) and VFAs with 2,3 , and $4 \mathrm{ft}(61,91$, and $122 \mathrm{~cm})$ radii produced incremental increases in vine biomass accumulation (Table

Table 1. The leaf, shoot, root and total dry weight and number of primary shoots and longest root per vine for 'Niagara' vines after one growing season. Treatments varied in the extent of the vegetation-free area maintained around vines.

\begin{tabular}{|c|c|c|c|c|c|c|}
\hline \multirow{3}{*}{$\begin{array}{l}\text { Radius } \\
\text { of } \\
\text { vegetation- } \\
\text { free area } \\
(\mathrm{ft})^{\mathrm{z}}\end{array}$} & \multicolumn{6}{|c|}{$\begin{array}{c}\text { Vine parameters } \\
\text { at harvest per vine }\end{array}$} \\
\hline & \multicolumn{4}{|c|}{ Dry wt (g) } & \multirow{2}{*}{$\begin{array}{c}\text { No. } \\
\text { of primary } \\
\text { shoots }\end{array}$} & \multirow{2}{*}{$\begin{array}{c}\text { Longest } \\
\text { root } \\
\text { (inches) }\end{array}$} \\
\hline & Leaf & Shoot & Root & Total & & \\
\hline 5 & $61.6 \mathrm{a}$ & $34.2 \mathrm{a}$ & $45.6 \mathrm{a}$ & $141.4 \mathrm{a}$ & $6.4 \mathrm{a}$ & $21 \mathrm{a}$ \\
\hline 4 & $60.2 \mathrm{a}$ & $34.4 \mathrm{a}$ & $53.4 \mathrm{a}$ & $148.0 \mathrm{a}$ & $5.8 \mathrm{ab}$ & $21 \mathrm{a}$ \\
\hline 3 & $34.0 \mathrm{~b}$ & $18.2 \mathrm{~b}$ & $29.3 \mathrm{~b}$ & 81.5 b & $4.6 \mathrm{bc}$ & $14 \mathrm{~b}$ \\
\hline 2 & $22.9 \mathrm{c}$ & $12.0 \mathrm{bc}$ & $21.2 \mathrm{bc}$ & $56.1 \mathrm{bc}$ & $5.0 \mathrm{abc}$ & $14 \mathrm{~b}$ \\
\hline 1 & $16.4 \mathrm{~cd}$ & $8.1 \mathrm{c}$ & $23.5 b c$ & $48.0 \mathrm{~cd}$ & $4.3 \mathrm{bc}$ & $11 \mathrm{bc}$ \\
\hline 0 & $9.3 \mathrm{~d}$ & $4.6 \mathrm{c}$ & $13.2 \mathrm{c}$ & $27.1 \mathrm{~d}$ & $3.4 \mathrm{c}$ & $9 c$ \\
\hline $\operatorname{LSD}_{(0.05)^{y}}{ }^{y}$ & 9.3 & 7.6 & 12.4 & 26.2 & 3.4 & 4 \\
\hline
\end{tabular}

\footnotetext{
${ }^{\mathrm{z}}$ Radii of $0,1,2,3,4$ and $5 \mathrm{ft}$ are equivalent to $0,30,61,91,122$ and $152 \mathrm{~cm}$, respectively.
}

${ }^{\mathrm{z}}$ Mean separation according to Fisher's test for least significant difference. $P \leq 0.05$. 
Table 2. The leaf, shoot, root and total dry weight and number of primary shoots and longest root per vine for 'Niagara' vines after one growing season. Treatments varied in the extent of the vegetation-free band maintained around vines.

\begin{tabular}{|c|c|c|c|c|c|c|}
\hline \multirow{3}{*}{$\begin{array}{l}\text { Width } \\
\text { of } \\
\text { vegetation- } \\
\text { free area } \\
(\mathrm{ft})^{\mathrm{z}} \\
\end{array}$} & \multicolumn{6}{|c|}{$\begin{array}{l}\text { Vine parameters } \\
\text { at harvest per vine }\end{array}$} \\
\hline & \multicolumn{4}{|c|}{ Dry wt (g) } & \multirow{2}{*}{$\begin{array}{c}\text { No. } \\
\text { of primary } \\
\text { shoots } \\
\end{array}$} & \multirow{2}{*}{$\begin{array}{c}\text { Longest } \\
\text { root } \\
\text { (inches) }\end{array}$} \\
\hline & Leaf & Shoot & Root & Total & & \\
\hline 8 & $54.2 \mathrm{a}$ & $32.5 \mathrm{a}$ & $48.1 \mathrm{a}$ & $134.8 \mathrm{a}$ & $4.3 \mathrm{a}$ & $28 \mathrm{a}$ \\
\hline 7 & 39.9 b & $23.5 \mathrm{~b}$ & $37.2 \mathrm{ab}$ & $100.6 \mathrm{~b}$ & $4.0 \mathrm{ab}$ & $26 \mathrm{ab}$ \\
\hline 5 & $27.1 \mathrm{c}$ & $16.7 \mathrm{~cd}$ & $29.3 \mathrm{bc}$ & $73.1 \mathrm{c}$ & $3.7 \mathrm{ab}$ & $23 \mathrm{bc}$ \\
\hline 4 & $14.7 \mathrm{~d}$ & $10.2 \mathrm{de}$ & $19.0 \mathrm{~cd}$ & $43.9 \mathrm{~d}$ & $3.5 \mathrm{ab}$ & $20 \mathrm{~cd}$ \\
\hline 3 & $13.6 \mathrm{~d}$ & $9.8 \mathrm{e}$ & $17.3 \mathrm{~d}$ & $40.7 \mathrm{~d}$ & $3.2 \mathrm{~b}$ & $19 \mathrm{~d}$ \\
\hline 0 & $1.1 \mathrm{e}$ & $2.3 \mathrm{f}$ & $5.0 \mathrm{e}$ & $8.4 \mathrm{e}$ & $2.2 \mathrm{c}$ & $12 \mathrm{e}$ \\
\hline $\operatorname{LSD}_{(0.05)}{ }^{\mathrm{y}}$ & 9.4 & 6.5 & 11.5 & 26.4 & 0.9 & 4 \\
\hline
\end{tabular}

zWidths of $0,3,4,5,6,7$ and $8 \mathrm{ft}$ are equivalent to $0,91,122,152,183,213$ and $244 \mathrm{~cm}$, respectively.

y Mean separation according to Fisher's test for least significant difference. $P \leq 0.05$.

1). However, there was no significant increase in vine biomass when the VFA radius increased from 4 to $5 \mathrm{ft}$ ( 122 to $152 \mathrm{~cm}$ ) (Table 1). Therefore, the threshold (Coble et al., 1981) for the development of maximum vine size in this experiment was a VFA with a radius of $4 \mathrm{ft}(122 \mathrm{~cm})$.

When the VFA around vines was established in a band, such as is typical in commercial vineyards, even the smallest VFA with a width of $3 \mathrm{ft}$ (91 $\mathrm{cm}$ ) significantly increased vine biomass accumulation and the length of the longest root on each vine over the control (Table 2). Significant incremental increases in leaf, shoot, root and total vine biomass occurred up to VFA band widths of $8,8,6$, and $8 \mathrm{ft}$ $(2.42 .4,1.8$, and $2.4 \mathrm{~m})$, respectively. Because the threshold for the development of maximum vine size was not reached under the conditions of this experiment, the threshold VFA is considered to be a VFA band width of at least $8 \mathrm{ft}(2.4 \mathrm{~m})$ (Table 2$)$.

The number of primary shoots per vine in both experiments increased as the VFA increased around vines. This is consistent with the observation of similar responses by young vines to combinations of weed control, irrigation and fertilization. Newly planted vines often produce more shoots with more leaf area in response to these cultural practices.

The VFA band width around vines in most Michigan and other eastern U.S. vineyards is about $4 \mathrm{ft}(122 \mathrm{~cm})$. These data indicate that on a light, sandy soil with a low water-holding capacity, there is a potential to increase vine growth in new vineyards by enlarging the VFA around vines unless it would cause an unacceptable risk of surface soil erosion.

\section{Literature cited}

Bordelon, B. and J. Hubertz. 1999. Growth of first-year grapevines in desiccated rye residues with and without follow-up weed control. HortScience 34(3):473.

Cahoon, G., M. Ellis, R. Williams, and L. Lockshin. 1991. Grapes: production, management and marketing. Ohio State Univ. Bul. 815 .

Coble, H.D., F.M. Williams, and R.L. Ritter. 1981. Common ragweed interference in soybeans. Weed Sci. 29:339-342.

Hipps, N.A., M.S. Ridout, and D. Atkinson. 1990. Effects of alley sward width, irrigation and nitrogen fertilizer on growth and yield of Cox's Orange Pippin apple trees. J. Sci. Food Agr. 53:159-168.

Kennedy, J.M., R.E. Talbert, and J.R. Morris. 1979. Weed control in 'Concord' grapes in Arkansas. J. Amer. Soc. Hort. Sci. 104:713-716.

Merwin, I.A. and J.A. Ray. 1997. Spatial and temporal factors in weed interference in newly planted apple trees. HortScience 32(4):633-637.

NeSmith, D.S. and G. Krewer. 1995. Veg- etation-free area influences growth and establishment of rabbiteye blueberry. HortScience 30(7):1410-1412.

Shaulis, N. and R.G.D. Steel. 1969. The interaction of resistant rootstock to nitrogen, weed control, pruning and thinning effects on the productivity of 'Concord' grapevines. J. Amer. Soc. Hort. Sci. 94:422429 .

Welker, W.V. and D.M. Glenn. 1985. The relationship of sod proximity to the growth and nutrient composition of newly planted peach trees. HortScience 20:417-418.

Welker, W.V. and D.M. Glenn. 1989. Sod proximity influences the growth and yield of young peach trees. J. Amer. Hort. Sci. $114(6): 856-859$.

Welker, W.V. and D.M. Glenn. 1991. Growth response of young peach trees to distribution pattern of vegetation-free area. HortScience 26(9):1141-1142.

Winkler, A.J., J.A. Cook, W.M. Kliewer, and L.A. Lider. 1974. General Viticulture. Univ. Calif. Press, Berkeley.

\Wolf, T.K. and E.B. Poling. 1995. The Mid-Atlantic wine grape grower's guide. N.C. State Univ., Raleigh.

Zabadal, T.J. 1997. Vineyard Establishment II - Planting and early care of vineyards. Mich. State Univ. Ext. Bul. E-2645.

Zabadal, T.J. and T.W. Dittmer. 2000. Influence of weed control, nitrogen fertilization, irrigation and pruning severity on the establishment of 'Niagara' grapevines. Small Fruits Rev. (in press). 